\title{
Systematic review of autosomal recessive ataxias and proposal for a classification
}

\author{
Marie Beaudin ${ }^{1}$, Christopher J. Klein², Guy A. Rouleau ${ }^{3}$ and Nicolas Dupré ${ }^{14^{*}}$
}

\begin{abstract}
Background: The classification of autosomal recessive ataxias represents a significant challenge because of high genetic heterogeneity and complex phenotypes. We conducted a comprehensive systematic review of the literature to examine all recessive ataxias in order to propose a new classification and properly circumscribe this field as new technologies are emerging for comprehensive targeted gene testing.

Methods: We searched Pubmed and Embase to identify original articles on recessive forms of ataxia in humans for which a causative gene had been identified. Reference lists and public databases, including OMIM and GeneReviews, were also reviewed. We evaluated the clinical descriptions to determine if ataxia was a core feature of the phenotype and assessed the available evidence on the genotype-phenotype association. Included disorders were classified as primary recessive ataxias, as other complex movement or multisystem disorders with prominent ataxia, or as disorders that may occasionally present with ataxia.
\end{abstract}

Results: After removal of duplicates, 2354 references were reviewed and assessed for inclusion. A total of 130 articles were completely reviewed and included in this qualitative analysis. The proposed new list of autosomal recessive ataxias includes 45 gene-defined disorders for which ataxia is a core presenting feature. We propose a clinical algorithm based on the associated symptoms.

Conclusion: We present a new classification for autosomal recessive ataxias that brings awareness to their complex phenotypes while providing a unified categorization of this group of disorders. This review should assist in the development of a consensus nomenclature useful in both clinical and research applications.

Keywords: Cerebellar ataxia, Spinocerebellar degenerations, Recessive, Genetics, Classification

\section{Background}

The classification of the hereditary ataxias has represented a challenge for decades due to the large heterogeneity of clinical presentations and the important overlap between different pathologies [1]. The first to propose a global classification for this group of disorders was Greenfield in 1954, whose classification was based on pathoanatomical findings [2]. This was followed by Harding's classification in 1983, which regrouped the ataxias according to age of onset, as a proxy for mode of inheritance, and clinical findings [3]. Although this clinical classification had merit, it quickly became overshadowed by a nomenclature based on gene discoveries

\footnotetext{
* Correspondence: nicolas.dupre.cha@ssss.gouv.qc.ca

${ }^{1}$ Faculty of Medicine, Université Laval, Quebec city, QC G1V 0A6, Canada ${ }^{4}$ Department of Neurological Sciences, CHU de Quebec - Université Laval, 1401 18th street, Québec City, QC G1J 1Z4, Canada

Full list of author information is available at the end of the article
}

within each specific type of ataxia starting with ATXN1 in Spinocerebellar ataxia 1 in 1993 [4] and FXN in Friedreich ataxia [5]. Since then, over 40 genes have been discovered in the dominant ataxias and as many in recessive ataxias [6].

One of the main challenges in the study of recessive ataxias is the difficulty to properly circumscribe which disorders belong to the field of hereditary ataxias and which belong to other disease categories. Indeed, ataxia is a cardinal symptom in cerebellar disorders, but may also be a presenting symptom of hereditary spastic paraplegias, hereditary polyneuropathies, neurodevelopmental disorders, and mitochondrial diseases, for example. Concurrently, recessive ataxias often manifest with complex phenotypes, even more so than their dominant counterparts, and may present diverse associated features including neuropathy, pyramidal and extrapyramidal involvement, oculomotor 


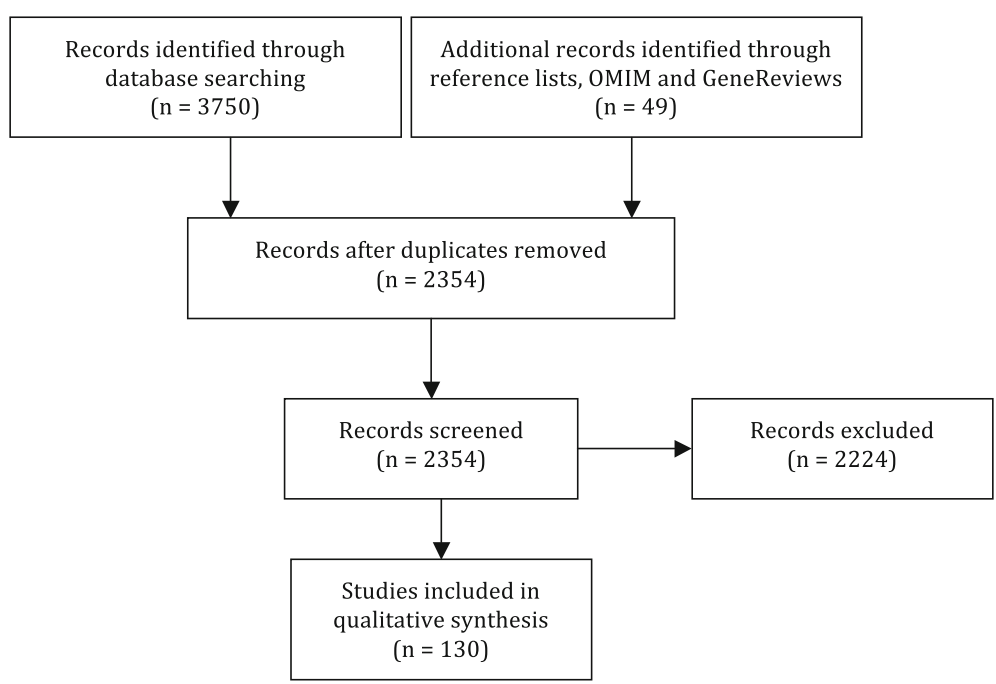

Fig. 1 Flow diagram

abnormalities, cognitive involvement, seizures, retinopathy, hypogonadism, and many others. This explains the high variability in the list of included disorders in recent literature reviews on recessive ataxias $[7,8]$.

Nevertheless, the advent of next generation sequencing techniques requires to properly determine which disorders belong to each disease category in order to design thoughtful targeted panels and facilitate the interpretation of whole exome and whole genome sequencing data. Indeed, targeted panel sequencing is a highly effective method for the diagnosis of neurological disorders, but it requires insightful categorization of disease phenotypes to respond to the specific needs of clinicians $[9,10]$. Similarly, the interpretation of unknown variants in the analysis of whole exome or whole genome sequencing data poses a significant challenge for clinicians who must determine if the gene is associated with the suspected disease category and if the phenotype correlates with what has previously been described. As next generation sequencing techniques become increasingly available and the ability to detect DNA repeat expansion diseases improves [11], the proper classification of diseases will represent a useful tool in the interpretation of test results. Hence, this calls for a systematic effort to review recessive diseases in which ataxia is a prominent feature in order for experts in the field to collectively determine which disorders should be included in a recessive ataxia classification.

Therefore, the purpose of this article is to review the literature on recessive diseases presenting with ataxia in order to present a new classification. The goal is to bring together experts for the development of a much-needed consensus that fulfills research and clinical needs.

\section{Methods}

We conducted a systematic review to identify articles relevant to the classification of autosomal recessive ataxias. We searched Pubmed and Embase from inception to September 2016 in order to identify original articles on disorders presenting with ataxia. The search strategy was large and targeted both recessive and sporadic ataxias, since recessive inheritance may appear sporadic in certain circumstances (full search strategy is provided in Additional file 1). We also reviewed reference lists of relevant articles and public databases including OMIM and GeneReviews to identify other relevant articles.

We reviewed the titles and abstracts of all identified references to select original articles on recessive forms of ataxia in humans for which a causative gene was identified. We evaluated the articles from a clinical perspective to determine if cerebellar ataxia was a prominent feature in the reported patients or rather a secondary finding in other movement or multisystem diseases. Diseases reporting only on cerebellar atrophy or cerebellar malformations without any clinical consequence were not included. For each listed disorder, we reviewed the evidence for a genotype-phenotype association using the US National Human Genome Research Institute guidelines [12]. Major considerations included the exclusion of previously described genes, the number of unrelated individuals described with similar genotype-phenotype correlations, the evidence of segregation with the disease, the absence of the variant in large control cohorts, and the presence of biochemical or animal-model functional validation. For the primary ataxias, we identified two relevant references from different research groups when possible. All relevant articles were fully reviewed to be included in this classification of recessive ataxias. 
Table 1 Proposed new list of autosomal recessive ataxias

\begin{tabular}{|c|c|c|c|c|}
\hline Disorder & Gene & OMIM & Additional clinical features and neuroimaging findings & $\begin{array}{l}\text { Relevant } \\
\text { references }\end{array}$ \\
\hline$\overline{C T X}$ & CYP27A1 & 213700 & $\begin{array}{l}\text { Dementia, paresis, tendon xanthomas, atherosclerosis, cataracts, elevated cholestanol } \\
\text { level, childhood onset, variable cerebellar atrophy, cerebellar or cerebral } \\
\text { leukodystrophy }\end{array}$ & {$[17,18]$} \\
\hline AVED & TTPA & 277460 & $\begin{array}{l}\text { Retinitis pigmentosa, head titubation, low serum vitamin E, teenage onset, spinal } \\
\text { cord atrophy, absence of cerebellar atrophy }\end{array}$ & {$[19,20]$} \\
\hline AT & ATM & 208900 & $\begin{array}{l}\text { Telangiectasias, oculomotor apraxia, photosensitivity, immunodeficiency, } \\
\text { predisposition for cancer, elevation of a-foetoprotein, infantile onset, cerebellar } \\
\text { atrophy }\end{array}$ & {$[21,22]$} \\
\hline FRDA & FXN & 229300 & $\begin{array}{l}\text { Bilateral Babinski sign, square-wave jerks, scoliosis, hypertrophic cardiomyopathy, } \\
\text { sensory involvement, teenage onset, spinal cord atrophy, absence of cerebellar } \\
\text { atrophy }\end{array}$ & {$[5,23]$} \\
\hline ATLD & MRE11 & 604391 & Oculomotor apraxia, childhood onset, cerebellar atrophy & {$[24,25]$} \\
\hline ARSACS & SACS & 270550 & $\begin{array}{l}\text { Spastic paraparesis, retinal striation, pes cavus, infantile or childhood onset, anterior } \\
\text { superior cerebellar atrophy, occasional T2-weighted linear hypointensities in pons }\end{array}$ & {$[26,27]$} \\
\hline $\mathrm{AOA} 1 / \mathrm{EAOH}$ & APTX & 208920 & $\begin{array}{l}\text { Oculomotor apraxia, cognitive impairment, hypoalbuminemia, hypercholesterolemia, } \\
\text { childhood onset, cerebellar atrophy }\end{array}$ & {$[28,29]$} \\
\hline SCAN1 & TDP1 & 607250 & $\begin{array}{l}\text { Peripheral axonal sensorimotor neuropathy, distal muscular atrophy, } \\
\text { hypercholesterolemia, teenage onset, cerebellar atrophy }\end{array}$ & {$[30,31]$} \\
\hline Cayman ataxia & ATCAY & 601238 & Psychomotor retardation, hypotonia, strabism, neonatal onset, cerebellar hypoplasia & {$[32,33]$} \\
\hline SANDO or MIRAS/SCAE & POLG1 & 607459 & $\begin{array}{l}\text { In SANDO, sensory ataxia, ophtalmoparesis, myoclonus, ptosis, adult onset, variable } \\
\text { cerebellar atrophy, cerebellar white matter lesions, strokelike lesions. In MIRAS, } \\
\text { cerebellar and sensitive ataxia, epilepsy, migraine, myoclonus, childhood or teenage } \\
\text { onset, signal abnormalities in cerebellum and thalamus }\end{array}$ & {$[34,35]$} \\
\hline $\mathrm{AOA} 2$ & SETX & 606002 & $\begin{array}{l}\text { Polyneuropathy, pyramidal signs, oculomotor apraxia, head tremor, chorea, dystonia, } \\
\text { elevation of a-foetoprotein, teenage onset, cerebellar atrophy }\end{array}$ & {$[36,37]$} \\
\hline CAMRQ1, DES & $V L D L R$ & 224050 & $\begin{array}{l}\text { Non-progressive cerebellar ataxia, mental retardation, hypotonia, strabismus, } \\
\text { occasional quadripedal gait, congenital onset, inferior cerebellar hypoplasia, cortical } \\
\text { gyral simplification }\end{array}$ & {$[38,39]$} \\
\hline $\begin{array}{l}\text { IOSCA/MTDPS7 (Allelic to } \\
\text { PEOA3) }\end{array}$ & C10orf2 & 271245 & $\begin{array}{l}\text { Athetosis, hypotonia, optic atrophy, ophtalmoplegia, hearing loss, epilepsy, } \\
\text { hypogonadism, liver involvement, infantile onset, moderate atrophy of brainstem } \\
\text { and cerebellum with advancing disease }\end{array}$ & {$[40,41]$} \\
\hline MSS & $S I L 1$ & 248800 & $\begin{array}{l}\text { Cataracts, mental retardation, myopathy, short stature, childhood onset, cerebellar } \\
\text { atrophy }\end{array}$ & {$[42,43]$} \\
\hline DCMA/MGCA5 & DNAJC19 & 610198 & $\begin{array}{l}\text { Dilated cardiomyopathy, non-progressive cerebellar ataxia, mental retardation, tes- } \\
\text { ticular dysgenesis, anemia, increased urinary 3-methylglutaconic acid, infantile onset }\end{array}$ & {$[44,45]$} \\
\hline ARCA1 & SYNE1 & 610743 & $\begin{array}{l}\text { Pure cerebellar ataxia, cognitive impairment, occasional pyramidal signs, late onset, } \\
\text { cerebellar atrophy }\end{array}$ & {$[46,47]$} \\
\hline ARCA2 & $\begin{array}{l}A D C K 3 \\
(C A B C 1)\end{array}$ & 612016 & $\begin{array}{l}\text { Exercise intolerance, epilepsy, myoclonus, cognitive impairment, childhood onset, } \\
\text { cerebellar atrophy, occasional strokelike cerebral lesions }\end{array}$ & {$[48,49]$} \\
\hline SeSAME syndrome & KCNJ10 & 612780 & $\begin{array}{l}\text { Epilepsy, sensorineural deafness, mental retardation, tubulopathy and electrolyte } \\
\text { imbalance, infantile onset, absence of cerebellar atrophy }\end{array}$ & {$[50,51]$} \\
\hline CAMRQ3 & CA8 & 613227 & $\begin{array}{l}\text { Mild mental retardation, occasional quadrupedal gait, congenital onset, cerebellar } \\
\text { atrophy, white matter abnormalities }\end{array}$ & {$[52,53]$} \\
\hline Salih ataxia/SCAR15 (1 family) & KIAA0226 & 615705 & Epilepsy, mental retardation, childhood onset, absence of cerebellar atrophy & {$[54,55]$} \\
\hline PHARC & ABHD12 & 612674 & $\begin{array}{l}\text { Sensorimotor neuropathy, cataract, hearing loss, retinitis pigmentosa, teenage onset, } \\
\text { variable cerebellar atrophy }\end{array}$ & {$[56,57]$} \\
\hline SPAX4 (1 family) & MTPAP & 613672 & Spastic paraparesis, optic atrophy, cognitive involvement, infantile onset & {$[58,59]$} \\
\hline ARCA3 & ANO10 & 613728 & $\begin{array}{l}\text { Cognitive impairment, downbeat nystagmus, teenage or adult onset, cerebellar } \\
\text { atrophy }\end{array}$ & {$[60,61]$} \\
\hline SCAR11 (1 family) & SYT14 & 614229 & Psychomotor retardation, late onset, cerebellar atrophy & [62] \\
\hline CAMRQ2 & WDR81 & 610185 & $\begin{array}{l}\text { Occasional quadrupedal gait, cognitive impairment, congenital onset, hypoplasia of } \\
\text { cerebellum and corpus callosum }\end{array}$ & {$[63,64]$} \\
\hline AOA3 (1 family) & PIK3R5 & 615217 & Oculomotor apraxia, sensorimotor involvement, teenage onset, cerebellar atrophy & [65] \\
\hline
\end{tabular}


Table 1 Proposed new list of autosomal recessive ataxias (Continued)

\begin{tabular}{|c|c|c|c|c|}
\hline SCAR13 & GRM1 & 614831 & $\begin{array}{l}\text { Cognitive impairment, mild pyramidal signs, short stature, seizures, congenital onset, } \\
\text { cerebellar atrophy }\end{array}$ & {$[66,67]$} \\
\hline CAMRQ4 (1 family) & ATP8A2 & 615268 & $\begin{array}{l}\text { Cognitive impairment, occasional quadrupedal gait, congenital onset, cerebellar and } \\
\text { cerebral atrophy }\end{array}$ & {$[68]$} \\
\hline SCAR7 (Allelic to CLN2) & TPP1 & 609270 & $\begin{array}{l}\text { Pyramidal signs, posterior column involvement, tremor, childhood onset, atrophy of } \\
\text { the cerebellum and pons }\end{array}$ & {$[69,70]$} \\
\hline $\begin{array}{l}\text { Ataxia and } \\
\text { hypogonadotropism }\end{array}$ & RNF216 & 212840 & $\begin{array}{l}\text { Hypogonadotropic hypogonadism, dementia, occasional chorea, childhood to } \\
\text { young adult onset, cerebellar and cerebral atrophy }\end{array}$ & {$[71,72]$} \\
\hline SCAR18 & GRID2 & 616204 & $\begin{array}{l}\text { Tonic upgaze, psychomotor retardation, retinal dystrophy, infantile onset, cerebellar } \\
\text { atrophy }\end{array}$ & {$[73,74]$} \\
\hline SCAR16 & STUB1 & 615768 & $\begin{array}{l}\text { Pyramidal signs, neuropathy, occasional hypogonadism, variable age at onset, } \\
\text { cerebellar atrophy }\end{array}$ & {$[75,76]$} \\
\hline SCAR12 & WWOX & 614322 & $\begin{array}{l}\text { Tonic-clonic epilepsy, mental retardation, spasticity, neonatal to childhood onset, } \\
\text { variable cerebellar or cerebral atrophy }\end{array}$ & {$[77,78]$} \\
\hline ATLD2 (1 family) & PCNA & 615919 & $\begin{array}{l}\text { Telangiectasias, sensorineural hearing loss, photosensitivity, cognitive impairment, } \\
\text { short stature, childhood onset, cerebellar atrophy }\end{array}$ & [79] \\
\hline SCAR20 & SNX14 & 616354 & $\begin{array}{l}\text { Mental retardation, sensorineural hearing loss, macrocephaly, dysmorphism, infantile } \\
\text { onset, cerebellar atrophy }\end{array}$ & {$[80,81]$} \\
\hline SCAR17 & CWF19L1 & 616127 & Mental retardation, congenital onset, cerebellar hypoplasia & {$[82,83]$} \\
\hline ACPHD (1 family) & DNAJC3 & 616192 & $\begin{array}{l}\text { Diabetes mellitus, UMN signs, demyelinating neuropathy, sensorineural hearing loss, } \\
\text { childhood to adult onset, generalized supra- and infratentorial atrophy }\end{array}$ & [84] \\
\hline LIKNS/SCAR19 (1 family) & SLC9A1 & 616291 & Sensorineural hearing loss, childhood onset, variable vermian atrophy & {$[85]$} \\
\hline AOA4 (Allelic to MCSZ) & PNKP & 616267 & $\begin{array}{l}\text { Dystonia, oculomotor apraxia, polyneuropathy, cognitive impairment, childhood } \\
\text { onset, cerebellar atrophy }\end{array}$ & {$[86,87]$} \\
\hline SCAR2 & PMPCA & 213200 & $\begin{array}{l}\text { Non-progressive cerebellar ataxia, cognitive impairment, pyramidal signs, short } \\
\text { stature, congenital or infantile onset, cerebellar atrophy }\end{array}$ & {$[88,89]$} \\
\hline SCAR21 & SCYL1 & 616719 & $\begin{array}{l}\text { Liver failure, peripheral neuropathy, mild cognitive impairment, childhood onset, } \\
\text { cerebellar vermis atrophy, thinning of optic nerve }\end{array}$ & [90] \\
\hline SCAR22 (1 family) & VWA3B & 616948 & $\begin{array}{l}\text { Cognitive impairment, pyramidal signs, adult onset, cerebellar atrophy and thin } \\
\text { corpus callosum }\end{array}$ & [91] \\
\hline SCAR23 (1 family) & TDP2 & 616949 & Tonic seizures, cognitive impairment, dysmorphism, childhood onset & [92] \\
\hline SCAR24 (1 family) & UBA5 & 617133 & Cataracts, peripheral neuropathy, childhood onset, cerebellar atrophy & [93] \\
\hline $\begin{array}{l}\text { Cerebellar ataxia with } \\
\text { developmental delay }(1 \\
\text { family) }\end{array}$ & THG1L & - & Psychomotor retardation, pyramidal signs, childhood onset, vermis hypoplasia & {$[94]$} \\
\hline \multicolumn{5}{|c|}{$\begin{array}{l}\text { ACPHD Ataxia, combined cerebellar and peripheral, with hearing loss and diabetes mellitus, AOA ataxia with oculomotor apraxia, ARCA autosomal recessive } \\
\text { cerebellar ataxia, ARSACS autosomal recessive spastic ataxia of Charlevoix-Saguenay, AT ataxia-telangiectasia, ATLD ataxia-telangiectasia-like disorder, AVED ataxia } \\
\text { with vitamin E deficiency, CA Cayman ataxia, CAMOS cerebellar ataxia mental retardation optic atrophy and skin abnormalities, CAMRQ cerebellar ataxia mental re } \\
\text { tardation with or without quadrupedal locomotion, DCMA Dilated cardiomyopathy with ataxia, DES Desequilibrium syndrome, EAOH early-onset ataxia with oculo- } \\
\text { motor apraxia and hypoalbuminemia, FRDA Friedreich ataxia, IOSCA infantile onset spinocerebellar ataxia, LIKNS Lichtenstein-Knorr syndrome, MGCA5 3- } \\
\text { methyglutaconic aciduria type 5, MIRAS mitochondrial recessive ataxia syndrome, MCSZ Microchephaly seizures developmental delay, MSS Marinesco-Sjogren syn- } \\
\text { drome, MTDPS7 mitochondrial DNA depletion syndrome 7, PEOA3 progressive external ophthalmoplegia with mitochondrial DNA deletions, autosomal dominant } \\
\text { 3, PHARC polyneuropathy hearing loss ataxia retinitis pigmentosa and cataract, SANDO sensory ataxic neuropathy with dysarthria and ophthalmoparesis, SCAE spi- } \\
\text { nocerebellar ataxia with epilepsy, SCAN1 spinocerebellar ataxia with axonal neuropathy 1, SCAR Spinocerebellar ataxia, autosomal recessive, SESAME Seizures sen- } \\
\text { sorineural deafness ataxia mental retardation and electrolyte imbalance, SPAX spastic ataxia, UMN upper motor neuron }\end{array}$} \\
\hline
\end{tabular}

Identified disorders were classified in three categories: the first included the primary autosomal recessive ataxias, the second included other movement or multisystem recessive diseases that have prominent ataxia, and the final group was composed of recessive disorders that may occasionally present with ataxia, but where ataxia is a secondary feature.

We also developed a clinical algorithm for the primary recessive ataxias based on the most frequent phenotype and cardinal symptoms associated with each disorder.
The objective of this algorithm is to rapidly summarize the main discriminatory features between different ataxias to serve in a clinical setting, but also as a pedagogical and research tool.

\section{Results}

3750 references were identified through the literature search in Pubmed and Embase, and 49 additional references were identified through reference lists or public databases. After removal of duplicates, 2354 references 
Table 2 Other complex movement or multisystem recessive disorders that have prominent ataxia

\begin{tabular}{|c|c|c|c|c|c|}
\hline Disorder & Gene & OMIM & Clinical features and imaging findings & Comment & References \\
\hline Abetalipoproteinemia & MTTP & 200100 & $\begin{array}{l}\text { Fat malabsorption symptoms, hypocholesterolemia, } \\
\text { hypotriglyceridemia, acanthocytosis, Friedreich-like ataxia, neo- } \\
\text { natal onset, absence of cerebellar atrophy }\end{array}$ & Multisystem & [95] \\
\hline \multirow[t]{2}{*}{ Nieman Pick type C } & NPC1 & 257220 & \multirow{2}{*}{$\begin{array}{l}\text { Vertical supranuclear ophtalmoplegia, ataxia, splenomegaly, } \\
\text { childhood to adult onset, variable cerebellar or cerebral atrophy }\end{array}$} & \multirow[t]{2}{*}{ Multisystem } & \multirow[t]{2}{*}[96,97]{} \\
\hline & $N P C 2$ & 607625 & & & \\
\hline Refsum disease & PAHX & 266500 & $\begin{array}{l}\text { Retinitis pigmentosa, polyneuropathy, ataxia, increased CSF } \\
\text { protein, anosmia, deafness, ichtyosis, teenage onset, elevated } \\
\text { serum phytanic acid, absence of cerebellar atrophy }\end{array}$ & Multisystem & {$[98,99]$} \\
\hline $\begin{array}{l}\text { Late-onset GM2 } \\
\text { gangliosidosis (Tay-Sachs, } \\
\text { Sandhoff) }\end{array}$ & $\begin{array}{l}\text { HEXA } \\
\text { HEXB }\end{array}$ & $\begin{array}{l}272800 \\
268800\end{array}$ & $\begin{array}{l}\text { Ataxia, dysarthria, intellectual impairment, extrapyramidal signs, } \\
\text { adult onset, cerebellar atrophy }\end{array}$ & $\begin{array}{l}\text { Lysosomal storage } \\
\text { disease }\end{array}$ & [100-102] \\
\hline SPARCA1 & SPTBN2 & 615386 & $\begin{array}{l}\text { Ataxia, cognitive impairment, eye-movement abnormalities, early } \\
\text { childhood onset, cerebellar atrophy }\end{array}$ & Allelic to SCA5 & {$[9,103]$} \\
\hline SPAX5 & AFG3L2 & 614487 & $\begin{array}{l}\text { Ataxia, spasticity, oculomotor apraxia, myoclonic epilepsy, } \\
\text { neuropathy, dystonia, optic atrophy, childhood onset, cerebellar } \\
\text { atrophy }\end{array}$ & Allelic to SCA28 & {$[104,105]$} \\
\hline $\begin{array}{l}\text { Boucher-Neuhauser/ } \\
\text { Gordon Holmes } \\
\text { syndrome }\end{array}$ & PNPLA6 & 215470 & $\begin{array}{l}\text { Ataxia, hypogonadotropic hypogonadism, chorioretinal } \\
\text { dystrophy or brisk reflexes, childhood onset, atrophy of } \\
\text { cerebellum and pons }\end{array}$ & Allelic to HSP39 & {$[106,107]$} \\
\hline Gillespie syndrome & ITPR1 & 206700 & $\begin{array}{l}\text { Non-progressive cerebellar ataxia, iris hypoplasia, cognitive } \\
\text { impairment, neonatal onset, progressive cerebellar atrophy }\end{array}$ & Allelic to SCA15/29 & [108] \\
\hline SPAX2/SPG58 & KIFIC & 611302 & $\begin{array}{l}\text { Spastic paraparesis, cerebellar ataxia, childhood or teenage } \\
\text { onset, white matter changes in the internal capsule }\end{array}$ & $\begin{array}{l}\text { Spasticity } \\
\text { predominant }\end{array}$ & {$[109,110]$} \\
\hline SPG7 & $S P G 7$ & 607259 & $\begin{array}{l}\text { Spasticity, pyramidal signs, cerebellar signs, optic neuropathy, } \\
\text { ptosis, teenage or adult onset, cerebellar atrophy }\end{array}$ & HSP & {$[111,112]$} \\
\hline SPG5 & CYP7B1 & 270800 & $\begin{array}{l}\text { Spasticity, cerebellar and sensory ataxia, childhood or teenage } \\
\text { onset, white matter lesions }\end{array}$ & HSP & {$[113,114]$} \\
\hline SPG11 & KIAA1840 & 604360 & $\begin{array}{l}\text { Spasticity, ataxia, cognitive impairment, sensorimotor } \\
\text { neuropathy, childhood or teenage onset, thin corpus callosum, } \\
\text { signal abnormalities in cervical cord }\end{array}$ & $\mathrm{HSP}$ & {$[115,116]$} \\
\hline SPG46 & GBA2 & 614409 & $\begin{array}{l}\text { Cerebellar ataxia, spastic dysarthria, mild cognitive impairment, } \\
\text { hearing loss, cataracts, childhood onset, cerebellar and cerebral } \\
\text { atrophy, thin corpus callosum }\end{array}$ & $\mathrm{HSP}$ & {$[117,118]$} \\
\hline $\begin{array}{l}\text { Congenital disorders of } \\
\text { glycosylation type } 1 \mathrm{~A}\end{array}$ & PMM2 & 212065 & $\begin{array}{l}\text { Psychomotor retardation, axial hypotonia, abnormal eye } \\
\text { movements, peripheral neuropathy, congenital onset, cerebellar } \\
\text { hypoplasia }\end{array}$ & $\begin{array}{l}\text { Neonatal onset, } \\
\text { complex syndrome }\end{array}$ & {$[119,120]$} \\
\hline LBSL & DARS2 & 611105 & $\begin{array}{l}\text { Cerebellar ataxia, tremor, spasticity, dorsal column dysfunction, } \\
\text { axonal neuropathy, childhood to adult onset, signal } \\
\text { abnormalities in cerebral white matter and specific brainstem } \\
\text { and spinal cord tracts }\end{array}$ & Leukoencephalopathy & {$[121,122]$} \\
\hline $\begin{array}{l}\text { Mitochondrial complex IV } \\
\text { deficiency }\end{array}$ & $\operatorname{cox} 20$ & 220110 & $\begin{array}{l}\text { Cerebellar ataxia, dystonia, sensory axonal neuropathy, variable, } \\
\text { childhood or teenage onset, cerebellar atrophy }\end{array}$ & $\begin{array}{l}\text { Dystonia } \\
\text { predominant }\end{array}$ & [123] \\
\hline Aceruloplas-minemia & $C P$ & 604290 & $\begin{array}{l}\text { Diabetes, dementia, movement disorder, cerebellar ataxia, retinal } \\
\text { degeneration, late onset, decreased signal intensity in thalamus, } \\
\text { basal ganglia and dentate nucleus }\end{array}$ & Metabolic disorder & [124] \\
\hline $\begin{array}{l}\text { Neurodegeneration with } \\
\text { brain iron accumulation } \\
2 \mathrm{~A} \text { and } 2 \mathrm{~B}\end{array}$ & PLA2G6 & 256600 & $\begin{array}{l}\text { Cerebellar ataxia, psychomotor retardation, psychiatric features, } \\
\text { axonal sensorimotor neuropathy, infantile or teenage onset, } \\
\text { cerebellar atrophy and variable iron accumulation in globus } \\
\text { pallidus }\end{array}$ & $\begin{array}{l}\text { Neurodegeneration } \\
\text { with brain iron } \\
\text { accumulation }\end{array}$ & {$[125,126]$} \\
\hline $\begin{array}{l}\text { Poretti-Botshauser } \\
\text { syndrome }\end{array}$ & LAMA1 & 615960 & $\begin{array}{l}\text { Nonprogressive ataxia, oculomotor ataxia, psychomotor } \\
\text { retardation, early childhood onset, cerebellar dysplasia with cysts }\end{array}$ & Dystroglycanopathy & [127] \\
\hline $\begin{array}{l}\text { Posterior column ataxia } \\
\text { with retinitis pigmentosa }\end{array}$ & FLVCR1 & 609033 & $\begin{array}{l}\text { Posterior column degeneration and retinitis pigmentosa, } \\
\text { childhood onset, signal abnormalities in cervical spinal cord }\end{array}$ & Sensory ataxia & {$[128,129]$} \\
\hline
\end{tabular}


Table 3 Recessive disorders that may occasionally present with ataxia, but where ataxia is a secondary feature

\begin{tabular}{|c|c|c|c|c|c|}
\hline Disorder & Gene & OMIM & Clinical features and imaging findings & Comment & References \\
\hline Neuronal ceroid lipofuscinoses & CLN5 CLN6 & $\begin{array}{l}256731 \\
601780\end{array}$ & $\begin{array}{l}\text { Psychomotor retardation, visual failure, seizures, } \\
\text { childhood to teenage onset, cerebellar and cerebral } \\
\text { atrophy }\end{array}$ & $\begin{array}{l}\text { Ataxia is a rare } \\
\text { feature }\end{array}$ & {$[130,131]$} \\
\hline $\begin{array}{l}\text { Sialic acid storage diseases (ISSD } \\
\text { and Salla disease) }\end{array}$ & SLC17A5 & $\begin{array}{l}604369 \\
269920\end{array}$ & $\begin{array}{l}\text { Hypotonia, cerebellar ataxia and mental retardation, } \\
\text { infantile to adult onset, cerebellar atrophy and } \\
\text { demyelination }\end{array}$ & $\begin{array}{l}\text { Complex } \\
\text { syndrome }\end{array}$ & {$[132,133]$} \\
\hline Joubert syndrome & $\begin{array}{l}\text { AHI1 } \\
\text { ARL13B } \\
\text { CC2D2A, } \\
\text { others }\end{array}$ & Many & $\begin{array}{l}\text { Ataxia, hypotonia, neonatal breathing abnormalities, } \\
\text { mental retardation, nephronophtisis, congenital onset, } \\
\text { agenesis of the cerebellar vermis }\end{array}$ & $\begin{array}{l}\text { Complex } \\
\text { neonatal } \\
\text { polygenic } \\
\text { syndrome }\end{array}$ & {$[134,135]$} \\
\hline Hartnup disorder & SLC6A19 & 234500 & $\begin{array}{l}\text { Transient manifestations of pellagra, cerebellar ataxia and } \\
\text { psychosis, amino aciduria, early onset }\end{array}$ & $\begin{array}{l}\text { Metabolic } \\
\text { disorder }\end{array}$ & [136] \\
\hline $\begin{array}{l}\text { Childhood ataxia with central } \\
\text { nervous system hypomyelination/ } \\
\text { vanishing white matter disease }\end{array}$ & elF2B & 603896 & $\begin{array}{l}\text { Cerebellar ataxia with spasticity. Rapid deterioration } \\
\text { following head trauma or febrile illness, infantile to adult } \\
\text { onset, diffusely abnormal cerebral white matter }\end{array}$ & Leukodystrophy & {$[137,138]$} \\
\hline L-2-Hydroxyglutaric aciduria & L2HGDH & 236792 & $\begin{array}{l}\text { Psychomotor retardation, epilepsy, macrocephaly, } \\
\text { cerebellar ataxia, infantile onset, subcortical } \\
\text { leukoencephalopathy and cerebellar atrophy }\end{array}$ & $\begin{array}{l}\text { Metabolic } \\
\text { disorder }\end{array}$ & {$[139,140]$} \\
\hline $\begin{array}{l}\text { GOSR2-linked progressive } \\
\text { myoclonus epilepsy }\end{array}$ & GOSR2 & 614018 & $\begin{array}{l}\text { Ataxia, myoclonic epilepsy, raised creatine kinase, early } \\
\text { childhood onset, variable cerebellar and cerebral atrophy }\end{array}$ & $\begin{array}{l}\text { Epileptic } \\
\text { disorder }\end{array}$ & [141] \\
\hline $\begin{array}{l}\text { Tremor-ataxia with central } \\
\text { hypomyelination }\end{array}$ & POLR3A & 607694 & $\begin{array}{l}\text { Tremor, cerebellar ataxia, cognitive regression, UMN signs, } \\
\text { childhood onset, hypomyelination of deep white matter, } \\
\text { cerebellar atrophy, thin corpus callosum }\end{array}$ & Leukodystrophy & [142] \\
\hline Recessive Behr's syndrome & OPA1 & 210000 & $\begin{array}{l}\text { Optic atrophy, ataxia, peripheral neuropathy, digestive } \\
\text { symptoms, infantile or childhood onset, cerebellar } \\
\text { atrophy }\end{array}$ & Optic atrophy & {$[143,144]$} \\
\hline
\end{tabular}

were reviewed on the basis of title and abstract. Finally, 130 articles were selected on the basis of the aforementioned criteria and completely reviewed to be included in this qualitative analysis (Fig. 1).

The proposed new list of autosomal recessive ataxias is presented in Table 1 in chronological order of gene discovery. The disorders included in this list were evaluated as having a relatively predominant cerebellar involvement compared to the involvement of other neurologic and non-neurologic systems. Table 2 presents the other complex motor or multisystem disorders that have prominent ataxia. Finally, Table 3 presents disorders that may occasionally present with ataxia, but where ataxia is a secondary feature. Certain decisions were made in the elaboration of this classification. Notably, abetalipoproteinemia (ABL) and Refsum disease were not included in the list of primary recessive ataxias, but rather in the list of complex disorders that have prominent ataxia. Indeed, despite their important Friedreich-like neurological picture, these disorders are primary lipid metabolism disorders with multisystem involvement. Moreover, ataxic disorders that are allelic to other movement disorders, especially spinocerebellar ataxias and hereditary spastic paraplegias, were assigned to the second category to avoid any confusion with the primary recessive ataxias. The MARS2-linked autosomal recessive ataxia with leukoencephalopathy (ARSAL/
SPAX3) was not included because the genetic evidence was deemed insufficient [13]. Finally, some disorders described only in single families were included, despite this being a factor for weaker genetic evidence, if other major considerations were met; this was indicated in the list.

The primary recessive ataxias were also organized in a clinical algorithm (Fig. 2) according to the presence of key clinical clues, which include the presence of sensorimotor involvement, cognitive impairment, spasticity, and oculomotor abnormalities.

Other disorders have been reported with ataxia, but the authors evaluated that these disorders did not need to be included in the differential diagnosis of recessive ataxias. However, clinicians may bear in mind that the following may have ataxia as an associated feature: Lafora disease (EPM2A, EPM2B), megalencephalic leukoencephalopathy with subcortical cysts (MLC1), COL18A1-linked ataxia epilepsy cognitive problems and visual problems, Perrault syndrome (HSD17B4), Zellweger-spectrum disorders (PEX2), Wolfram syndrome (WFS1), Canavan disease (ASPA), metachromatic leukodystrophy (ARSA), Galloway-Mowat syndrome (WDR73), and GLUT-1 deficiency (SCL2A1).

\section{Discussion}

We present a new classification for the autosomal recessive ataxias. This classification should allow for better 


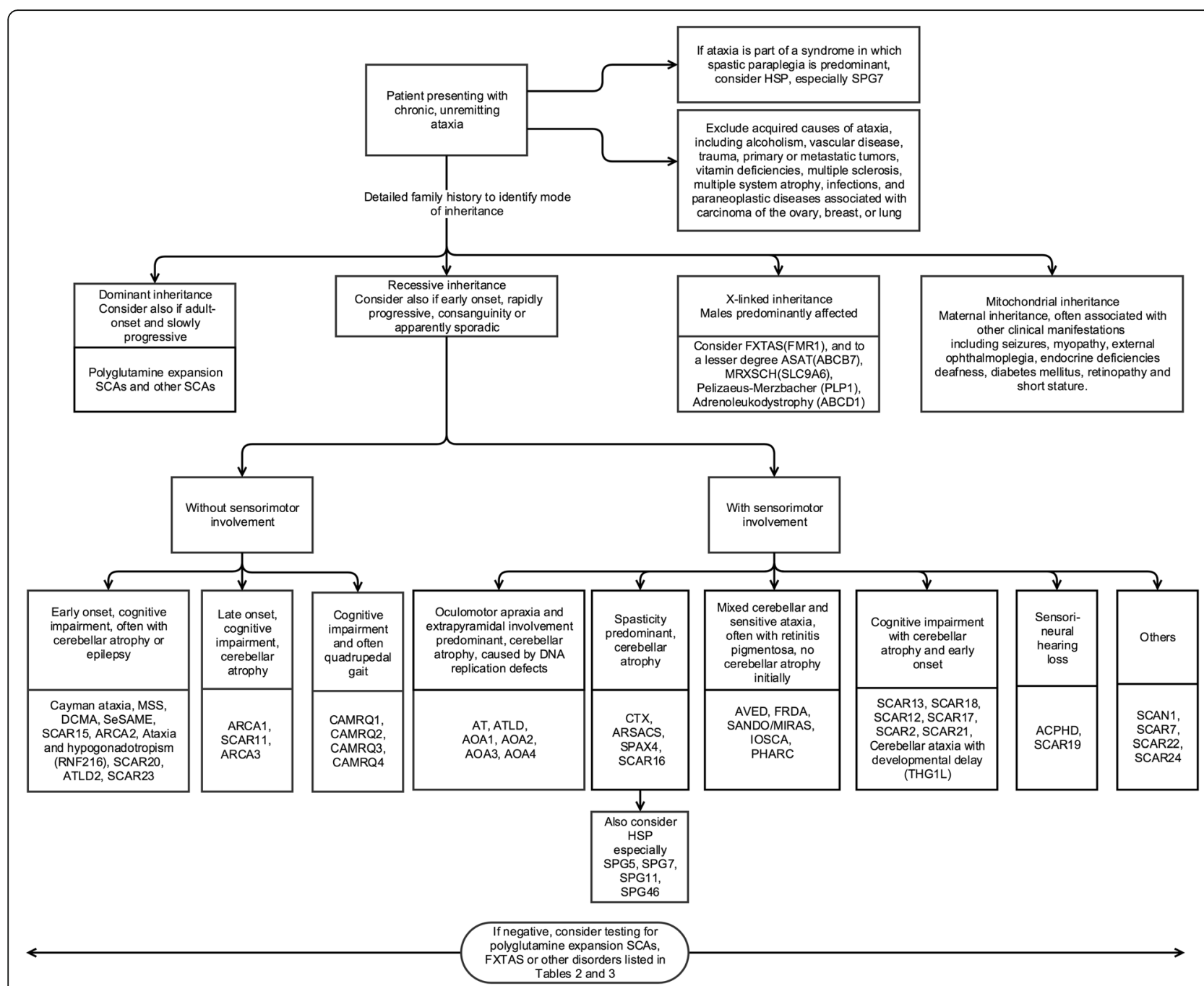

Fig. 2 Clinical algorithm of autosomal recessive ataxias

categorization of recessive disorders presenting with ataxia with a clear separation between the primary recessive ataxias and disorders that may present with ataxia as an associated feature but belong to other disease categories. We also provided a clinical algorithm as a tool for diagnostic, learning, and research purposes. This comprehensive classification will allow for improved genetic diagnosis by targeted next generation sequencing applications as the ability to detect DNA repeat expansion diseases is quickly becoming a reality with prospects of treatment in the future $[11,14,15]$.

As compared to previously published reports on this subject $[7,8]$, we systematically reviewed the literature to evaluate the available evidence on the diseaseassociated genes in order to include all disorders presenting with a predominant cerebellar ataxia phenotype. The systematic review methodology with a structured data search and comprehensive evaluation of all references allowed for a complete evaluation of the literature regarding disorders presenting with ataxia to ensure that all potentially relevant disorders were included in this classification. Nevertheless, some methodological elements were not applicable to the task at hand. For example, two references were selected for each primary recessive ataxia, and articles that provided evidence for a separate genetic basis with a clinical corollary of ataxia were preferred. Therefore, some articles that provided only detailed clinical description were not included. Moreover, inclusion criteria were clearly defined but there remained a place for interpretation to determine if cerebellar ataxia was a core feature of the phenotype and if the genotype-phenotype association was convincing. Thus, the classification of individual disorders between the three groups, i.e. as a recessive ataxia, a complex disorder with predominant ataxia or a disorder where ataxia is a secondary feature, remains a subjective appreciation and is open for discussion by a dedicated task force in order to reach a consensus. Finally, the search 
strategy was designed to be as sensible as possible, but ataxia is a frequent symptom in neurology, and it is possible that other ataxia-associated disorders could be considered for inclusion.

Important challenges remain to be addressed. First, the nosology of recessive ataxias is still highly confusing. Contrary to the dominantly inherited spinocerebellar ataxias, no universal acronym was adopted in the field of recessive ataxias, such that disorders were named based on the author who first described them, on regions of high prevalence, or according to clinical presentation. In the last few years, the term spinocerebellar ataxia, autosomal recessive (SCAR) was used to designate novel recessive ataxias, but this nomenclature did not include the previously described and most frequent ataxias. Moreover, as SCAR assignation was based on locus discovery, some of the included SCARs do not correspond to an identified gene. The term SPAX has also been used to designate ataxias with a strong spasticity component, irrespectively of their mode of inheritance. Recently, the International Parkinson and Movement Disorder Society Task Force for Nomenclature of Genetic Movement Disorders recommended a nomenclature with a gene suffix in order to overcome the shortcomings of the numbered locus system, which include erroneously assigned loci, the mingling of causative and risk factor genes, unconfirmed causative associations, and inconsistent phenotypic correlations [16]. These concerns are justified, although numbered naming systems present definite advantages for ease of use and proper delineation of the field. The nomenclature of recessive ataxias should be discussed by a dedicated task force of international experts in order to develop a naming system that reflects the complexity of the recessive ataxia phenotypes while allowing convenient clinical use.

Finally, large phenotypic variability exists between patients from different families and even from a single family with the same mutated gene, depending on the type of mutation and on its location in the gene. Other factors that affect age at onset and clinical course probably include the presence of modifier genes and environmental exposures. Hence, one could argue that the paradigm of one gene-one disease presented here does not reflect all the phenotypic variability observed, and could as well be replaced by the concept of one patientone disease as we identify new genetic and environmental prognostic features that characterise more precisely the age at onset, evolution, and response to treatment. Such developments are likely to modify our understanding of genetic disorders and of their classification.

\section{Conclusion}

We present herein a classification of the autosomal recessive ataxias based on a systematic review of the literature. This work should serve as a framework for scientific discussion in order to bring together experts for the establishment of a much-needed consensus in this field.

\section{Additional file}

Additional file 1: Search strategy for MEDLINE/PubMed. (DOCX 41 kb)

\section{Acknowledgements \\ Not applicable. \\ Funding \\ MB is supported by the Canadian Institutes of Health Research. This study was conducted independently of the funding body.}

Availability of data and materials

The dataset of records screened for publication generated during this study can be obtained using the search strategy provided in the additional file.

\section{Authors' contributions}

MB designed the search strategy, conducted the systematic review, and drafted the manuscript. CJK, GAR, and ND provided essential intellectual input and revised the manuscript. All authors read and approved the final manuscript.

\section{Competing interests}

The authors declare that they have no competing interests.

Consent for publication

Not applicable.

Ethics approval and consent to participate

Not applicable.

\section{Author details}

${ }^{1}$ Faculty of Medicine, Université Laval, Quebec city, QC G1V 0A6, Canada. 2Department of Neurology, Mayo Clinic, Rochester, MN 55905, USA. ${ }^{3}$ Department of Neurology and Neurosurgery, McGill University, Montreal, QC H3A 1A4, Canada. ${ }^{4}$ Department of Neurological Sciences, CHU de Quebec Université Laval, 1401 18th street, Québec City, QC G1J 1Z4, Canada.

Received: 22 November 2016 Accepted: 17 February 2017

Published online: 23 February 2017

References

1. Online Mendelian Inheritance in Man, $\mathrm{OMIM}^{\circledast}$. McKusick-Nathans Institute of Genetic Medicine, Johns Hopkins University, Baltimore MD. https://omim. org/. Accessed 15 Sept 2016.

2. Greenfield JG. The Spincoerebellar Degenerations. Oxford: Blackwell; 1954.

3. Harding AE. Classification of the hereditary ataxias and paraplegias. Lancet. 1983:1:1151-5.

4. Orr HT, Chung MY, Banfi S, Kwiatkowski Jr TJ, Servadio A, Beaudet AL, McCall AE, Duvick LA, Ranum LP, Zoghbi HY. Expansion of an unstable trinucleotide CAG repeat in spinocerebellar ataxia type 1. Nat Genet. 1993;4: 221-6.

5. Campuzano V, Montermini L, Molto MD, Pianese L, Cossee M, Cavalcanti F, Monros E, Rodius F, Duclos F, Monticelli A, et al. Friedreich's ataxia: autosomal recessive disease caused by an intronic GAA triplet repeat expansion. Science. 1996;271:1423-7.

6. Bird TD. In: Pagon RA, Adam MP, Ardinger HH, Wallace SE, Amemiya A, Bean LJH, Bird TD, Ledbetter N, Mefford HC, Smith RJH, Stephens K, editors. Hereditary Ataxia Overview. Seattle: GeneReviews (R); 1993.

7. Anheim M, Tranchant C, Koenig M. The autosomal recessive cerebellar ataxias. N Engl J Med. 2012;366:636-46.

8. Vermeer $S$, van de Warrenburg BP, Willemsen MA, Cluitmans M, Scheffer $H$, Kremer BP, Knoers NV. Autosomal recessive cerebellar ataxias: the current state of affairs. J Med Genet. 2011;48:651-9. 
9. Nemeth AH, Kwasniewska AC, Lise S, Parolin Schnekenberg R, Becker EB, Bera KD, Shanks ME, Gregory L, Buck D, Zameel Cader M, et al. Next generation sequencing for molecular diagnosis of neurological disorders using ataxias as a model. Brain. 2013;136:3106-18.

10. Ankala A, Da Silva C, Gualandi F, Ferlini A, Bean L, Collins C, Tanner AK, Hegde MR. A comprehensive genomic approach for neuromuscular diseases gives a high diagnostic yield. Ann Neurol. 2015;77:206-14.

11. Rhoads A, Au KF. PacBio Sequencing and Its Applications. Genomics Proteomics Bioinformatics. 2015;13:278-89.

12. MacArthur DG, Manolio TA, Dimmock DP, Rehm HL, Shendure J, Abecasis GR, Adams DR, Altman RB, Antonarakis SE, Ashley EA, et al. Guidelines for investigating causality of sequence variants in human disease. Nature. 2014; 508:469-76.

13. Bayat $V$, Thiffault I, Jaiswal M, Tetreault M, Donti T, Sasarman F, Bernard G, Demers-Lamarche J, Dicaire MJ, Mathieu J, et al. Mutations in the mitochondrial methionyl-tRNA synthetase cause a neurodegenerative phenotype in flies and a recessive ataxia (ARSAL) in humans. PLoS Biol. 2012;10, e1001288.

14. Cinesi $C$, Aeschbach $L$, Yang B, Dion V. Contracting CAG/CTG repeats using the CRISPR-Cas9 nickase. Nat Commun. 2016;7:13272.

15. Loomis EW, Eid JS, Peluso P, Yin J, Hickey L, Rank D, McCalmon S, Hagerman RJ, Tassone F, Hagerman PJ. Sequencing the unsequenceable: expanded CGGrepeat alleles of the fragile X gene. Genome Res. 2013;23:121-8.

16. Marras C, Lang A, van de Warrenburg BP, Sue CM, Tabrizi SJ, Bertram L, Mercimek-Mahmutoglu S, Ebrahimi-Fakhari D, Warner TT, Durr A, et al. Nomenclature of genetic movement disorders: Recommendations of the international Parkinson and movement disorder society task force. Mov Disord. 2016;31:436-57.

17. Cali JJ, Hsieh CL, Francke U, Russell DW. Mutations in the bile acid biosynthetic enzyme sterol 27-hydroxylase underlie cerebrotendinous xanthomatosis. J Biol Chem. 1991;266:7779-83.

18. Leitersdorf E, Reshef A, Meiner V, Levitzki R, Schwartz SP, Dann EJ, Berkman N, Cali JJ, Klapholz L, Berginer VM. Frameshift and splice-junction mutations in the sterol 27-hydroxylase gene cause cerebrotendinous xanthomatosis in Jews or Moroccan origin. J Clin Invest. 1993;91:2488-96.

19. Ouahchi K, Arita M, Kayden H, Hentati F, Ben Hamida M, Sokol R, Arai H, Inoue $\mathrm{K}$, Mandel $\mathrm{J}$, Koenig M. Ataxia with isolated vitamin E deficiency is caused by mutations in the alpha-tocopherol transfer protein. Nat Genet. 1995;9:141-5.

20. Yokota T, Shiojiri T, Gotoda T, Arita M, Arai H, Ohga T, Kanda T, Suzuki J, Imai

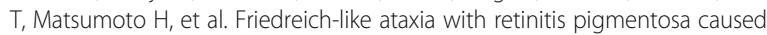
by the His101GIn mutation of the alpha-tocopherol transfer protein gene. Ann Neurol. 1997:41:826-32.

21. Savitsky K, Bar-Shira A, Gilad S, Rotman G, Ziv Y, Vanagaite L, Tagle DA Smith S, Uziel T, Sfez S, et al. A single ataxia telangiectasia gene with a product similar to PI-3 kinase. Science. 1995;268:1749-53.

22. Wright J, Teraoka S, Onengut S, Tolun A, Gatti RA, Ochs HD, Concannon P. A high frequency of distinct ATM gene mutations in ataxia-telangiectasia. Am J Hum Genet. 1996;59:839-46.

23. Durr A, Cossee M, Agid Y, Campuzano V, Mignard C, Penet C, Mandel JL, Brice A, Koenig M. Clinical and genetic abnormalities in patients with Friedreich's ataxia. N Engl J Med. 1996;335:1169-75.

24. Stewart GS, Maser RS, Stankovic T, Bressan DA, Kaplan MI, Jaspers NG, Raams A, Byrd PJ, Petrini JH, Taylor AM. The DNA double-strand break repair gene hMRE11 is mutated in individuals with an ataxia-telangiectasia-like disorder. Cell. 1999;99:577-87.

25. Pitts SA, Kullar HS, Stankovic T, Stewart GS, Last Jl, Bedenham T, Armstrong SJ, Piane M, Chessa L, Taylor AM, Byrd PJ. hMRE11: genomic structure and a null mutation identified in a transcript protected from nonsense-mediated mRNA decay. Hum Mol Genet. 2001;10:1155-62.

26. Engert JC, Berube P, Mercier J, Dore C, Lepage P, Ge B, Bouchard JP, Mathieu J, Melancon SB, Schalling M, et al. ARSACS, a spastic ataxia common in northeastern Quebec, is caused by mutations in a new gene encoding an 11.5-kb ORF. Nat Genet. 2000;24:120-5.

27. Criscuolo C, Banfi S, Orio M, Gasparini P, Monticelli A, Scarano V, Santorelli FM, Perretti A, Santoro L, De Michele G, Filla A. A novel mutation in SACS gene in a family from southern Italy. Neurology. 2004;62:100-2.

28. Moreira MC, Barbot C, Tachi N, Kozuka N, Uchida E, Gibson T, Mendonca P, Costa M, Barros J, Yanagisawa T, et al. The gene mutated in ataxia-ocular apraxia 1 encodes the new HIT/Zn-finger protein aprataxin. Nat Genet. 2001;29:189-93.

29. Date $\mathrm{H}$, Onodera $\mathrm{O}$, Tanaka H, Iwabuchi K, Uekawa $\mathrm{K}$, Igarashi S, Koike $\mathrm{R}$, Hiroi T, Yuasa T, Awaya Y, et al. Early-onset ataxia with ocular motor apraxia and hypoalbuminemia is caused by mutations in a new HIT superfamily gene. Nat Genet. 2001;29:184-8.

30. Takashima H, Boerkoel CF, John J, Saifi GM, Salih MA, Armstrong D, Mao Y, Quiocho FA, Roa BB, Nakagawa M, et al. Mutation of TDP1, encoding a topoisomerase I-dependent DNA damage repair enzyme, in spinocerebellar ataxia with axonal neuropathy. Nat Genet. 2002;32:267-72.

31. El-Khamisy SF, Saifi GM, Weinfeld M, Johansson F, Helleday T, Lupski JR, Caldecott KW. Defective DNA single-strand break repair in spinocerebellar ataxia with axonal neuropathy-1. Nature. 2005;434:108-13.

32. Bomar JM, Benke PJ, Slattery EL, Puttagunta R, Taylor LP, Seong E, Nystuen A, Chen W, Albin RL, Patel PD, et al. Mutations in a novel gene encoding a CRAL-TRIO domain cause human Cayman ataxia and ataxia/dystonia in the jittery mouse. Nat Genet. 2003;35:264-9.

33. Manzoor $H$, Brüggemann N, Hinrichs F, Hussain HMJ, Wajid M, Bäumer T, Münchau A, Naz S, Lohmann K. Exome sequencing reveals homozygous mutations in SACS, ATCAY, and MCOLN1 in three Pakistani families with complex dystonia. Mov Disord. 2016;31:S535.

34. Van Goethem G, Martin JJ, Dermaut B, Lofgren A, Wibail A, Ververken D, Tack P, Dehaene I, Van Zandijcke M, Moonen M, et al. Recessive POLG mutations presenting with sensory and ataxic neuropathy in compound heterozygote patients with progressive external ophthalmoplegia. Neuromuscul Disord. 2003;13:133-42.

35. Winterthun S, Ferrari G, He L, Taylor RW, Zeviani M, Turnbull DM, Engelsen BA, Moen $\mathrm{G}$, Bindoff LA. Autosomal recessive mitochondrial ataxic syndrome due to mitochondrial polymerase gamma mutations. Neurology. 2005;64:1204-8.

36. Moreira MC, Klur S, Watanabe M, Nemeth AH, Le Ber I, Moniz JC, Tranchant C, Aubourg P, Tazir M, Schols L, et al. Senataxin, the ortholog of a yeast RNA helicase, is mutant in ataxia-ocular apraxia 2. Nat Genet. 2004;36:225-7.

37. Le Ber I, Bouslam N, Rivaud-Pechoux S, Guimaraes J, Benomar A, Chamayou C, Goizet C, Moreira MC, Klur S, Yahyaoui M, et al. Frequency and phenotypic spectrum of ataxia with oculomotor apraxia 2: a clinical and genetic study in 18 patients. Brain. 2004;127:759-67.

38. Boycott KM, Flavelle S, Bureau A, Glass HC, Fujiwara TM, Wirrell E, Davey K, Chudley AE, Scott JN, McLeod DR, Parboosingh JS. Homozygous deletion of the very low density lipoprotein receptor gene causes autosomal recessive cerebellar hypoplasia with cerebral gyral simplification. Am J Hum Genet. 2005;77:477-83.

39. Moheb LA, Tzschach A, Garshasbi M, Kahrizi K, Darvish H, Heshmati Y, Kordi A, Najmabadi H, Ropers HH, Kuss AW. Identification of a nonsense mutation in the very low-density lipoprotein receptor gene (VLDLR) in an Iranian family with dysequilibrium syndrome. Eur J Hum Genet. 2008;16:270-3.

40. Nikali K, Suomalainen A, Saharinen J, Kuokkanen M, Spelbrink JN, Lonnqvist $\mathrm{T}$, Peltonen $\mathrm{L}$. Infantile onset spinocerebellar ataxia is caused by recessive mutations in mitochondrial proteins Twinkle and Twinky. Hum Mol Genet. 2005:14:2981-90

41. Hakonen AH, Isohanni P, Paetau A, Herva R, Suomalainen A, Lonnqvist T. Recessive Twinkle mutations in early onset encephalopathy with mtDNA depletion. Brain. 2007;130:3032-40.

42. Anttonen AK, Mahineh I, Hamalainen RH, Lagier-Tourenne C, Kopra O, Waris $\mathrm{L}$, Anttonen M, Joensuu T, Kalimo H, Paetau A, et al. The gene disrupted in Marinesco-Sjogren syndrome encodes SIL1, an HSPA5 cochaperone. Nat Genet. 2005;37:1309-11

43. Senderek J, Krieger M, Stendel C, Bergmann C, Moser M, Breitbach-Faller N, Rudnik-Schoneborn S, Blaschek A, Wolf NI, Harting I, et al. Mutations in SIL1 cause Marinesco-Sjogren syndrome, a cerebellar ataxia with cataract and myopathy. Nat Genet. 2005;37:1312-4.

44. Davey KM, Parboosingh JS, MCLeod DR, Chan A, Casey R, Ferreira P, Snyder FF, Bridge PJ, Bernier FP. Mutation of DNAJC19, a human homologue of yeast inner mitochondrial membrane co-chaperones, causes DCMA syndrome, a novel autosomal recessive Barth syndrome-like condition. J Med Genet. 2006;43:385-93.

45. Al Teneiji A, Siriwardena K, George K, Mital S, Mercimek-Mahmutoglu S. Progressive Cerebellar Atrophy and a Novel Homozygous Pathogenic DNAJC19 Variant as a Cause of Dilated Cardiomyopathy Ataxia Syndrome. Pediatr Neurol. 2016;62:58-61.

46. Gros-Louis F, Dupre N, Dion P, Fox MA, Laurent S, Verreault S, Sanes JR, Bouchard JP, Rouleau GA. Mutations in SYNE1 lead to a newly discovered form of autosomal recessive cerebellar ataxia. Nat Genet. 2007;39:80-5.

47. Izumi Y, Miyamoto R, Morino H, Yoshizawa A, Nishinaka K, Udaka F, Kameyama M, Maruyama H, Kawakami H. Cerebellar ataxia with SYNE1 mutation accompanying motor neuron disease. Neurology. 2013;80. 
48. Lagier-Tourenne C, Tazir M, Lopez LC, Quinzii CM, Assoum M, Drouot N, Busso C, Makri S, Ali-Pacha L, Benhassine T, et al. ADCK3, an ancestral kinase, is mutated in a form of recessive ataxia associated with coenzyme Q10 deficiency. Am J Hum Genet. 2008;82:661-72.

49. Mollet J, Delahodde A, Serre V, Chretien D, Schlemmer D, Lombes A, Boddaert N, Desguerre I, De Lonlay P, De Baulny HO, et al. CABC1 gene mutations cause ubiquinone deficiency with cerebellar ataxia and seizures. Am J Hum Genet. 2008;82:623-30.

50. Bockenhauer D, Feather S, Stanescu HC, Bandulik S, Zdebik AA, Reichold M, Tobin J, Lieberer E, Sterner C, Landoure G, et al. Epilepsy, ataxia, sensorineural deafness, tubulopathy, and KCNJ10 mutations. N Engl J Med. 2009;360:1960-70.

51. Scholl UI, Choi M, Liu T, Ramaekers VT, Hausler MG, Grimmer J, Tobe SW, Farhi A, Nelson-Williams C, Lifton RP. Seizures, sensorineural deafness, ataxia, mental retardation, and electrolyte imbalance (SeSAME syndrome) caused by mutations in KCNJ10. Proc Natl Acad Sci U S A. 2009;106:5842-7.

52. Turkmen S, Guo G, Garshasbi M, Hoffmann K, Alshalah AJ, Mischung C, Kuss A, Humphrey N, Mundlos S, Robinson PN. CA8 mutations cause a novel syndrome characterized by ataxia and mild mental retardation with predisposition to quadrupedal gait. PLoS Genet. 2009;5, e1000487.

53. Kaya N, Aldhalaan H, Al-Younes B, Colak D, Shuaib T, Al-Mohaileb F, AlSugair A, Nester M, Al-Yamani S, Al-Bakheet A, et al. Phenotypical spectrum of cerebellar ataxia associated with a novel mutation in the CA8 gene, encoding carbonic anhydrase (CA) VIII. Am J Med Genet B Neuropsychiatr Genet. 2011;156b:826-34

54. Assoum M, Salih MA, Drouot N, H'Mida-Ben Brahim D, Lagier-Tourenne C, AIDrees A, Elmalik SA, Ahmed TS, Seidahmed MZ, Kabiraj MM, Koenig M. Rundataxin, a novel protein with RUN and diacylglycerol binding domains, is mutant in a new recessive ataxia. Brain. 2010;133:2439-47.

55. Assoum M, Salih MA, Drouot N, Hnia K, Martelli A, Koenig M. The Salih ataxia mutation impairs Rubicon endosomal localization. Cerebellum. 2013;12:835-40.

56. Fiskerstrand T, H'Mida-Ben Brahim D, Johansson S, M'Zahem A, Haukanes BI, Drouot N, Zimmermann J, Cole AJ, Vedeler C, Bredrup C, et al. Mutations in ABHD12 cause the neurodegenerative disease PHARC: An inborn error of endocannabinoid metabolism. Am J Hum Genet. 2010;87:410-7.

57. Eisenberger T, Slim R, Mansour A, Nauck M, Nurnberg G, Nurnberg P, Decker C, Dafinger C, Ebermann I, Bergmann C, Bolz HJ. Targeted next-generation sequencing identifies a homozygous nonsense mutation in ABHD12, the gene underlying PHARC, in a family clinically diagnosed with Usher syndrome type 3. Orphanet J Rare Dis. 2012;7:59.

58. Crosby AH, Patel H, Chioza BA, Proukakis C, Gurtz K, Patton MA, Sharifi R, Harlalka G, Simpson MA, Dick K, et al. Defective mitochondrial mRNA maturation is associated with spastic ataxia. Am J Hum Genet. 2010;87:655-60.

59. Wilson WC, Hornig-Do HT, Bruni F, Chang JH, Jourdain AA, Martinou JC, Falkenberg M, Spahr H, Larsson NG, Lewis RJ, et al. A human mitochondrial poly (A) polymerase mutation reveals the complexities of post-transcriptional mitochondrial gene expression. Hum Mol Genet. 2014;23:6345-55.

60. Vermeer S, Hoischen A, Meijer RP, Gilissen C, Neveling K, Wieskamp N, De Brouwer A, Koenig M, Anheim M, Assoum M, et al. Targeted nextgeneration sequencing of a $12.5 \mathrm{Mb}$ homozygous region reveals ANO10 mutations in patients with autosomal-recessive cerebellar ataxia. Am J Hum Genet. 2010;87:813-9.

61. Chamova T, Florez L, Guergueltcheva V, Raycheva M, Kaneva R, Lochmuller H, Kalaydjieva L, Tournev I. ANO10 c.1150_1151del is a founder mutation causing autosomal recessive cerebellar ataxia in Roma/Gypsies. J Neurol. 2012;259:906-11.

62. Doi H, Yoshida K, Yasuda T, Fukuda M, Fukuda Y, Morita H, Ikeda S, Kato R, Tsurusaki $Y$, Miyake N, et al. Exome sequencing reveals a homozygous SYT14 mutation in adult-onset, autosomal-recessive spinocerebellar ataxia with psychomotor retardation. Am J Hum Genet. 2011;89:320-7.

63. Gulsuner $\mathrm{S}$, Tekinay AB, Doerschner $\mathrm{K}$, Boyaci $H$, Bilguvar $\mathrm{K}$, Unal H, Ors A, Onat OE, Atalar E, Basak AN, et al. Homozygosity mapping and targeted genomic sequencing reveal the gene responsible for cerebellar hypoplasia and quadrupedal locomotion in a consanguineous kindred. Genome Res. 2011:21:1995-2003.

64. Komara M, John A, Suleiman J, Ali BR, Al-Gazali L. Clinical and molecular delineation of dysequilibrium syndrome type 2 and profound sensorineural hearing loss in an inbred Arab family. Am J Med Genet A. 2016;170a:540-3.

65. Al Tassan N, Khalil D, Shinwari J, Al Sharif L, Bavi P, Abduljaleel Z, Abu Dhaim N, Magrashi A, Bobis S, Ahmed H, et al. A missense mutation in PIK3R5 gene in a family with ataxia and oculomotor apraxia. Hum Mutat. 2012;33:351-4
66. Guergueltcheva V, Azmanov DN, Angelicheva D, Smith KR, Chamova T, Florez L, Bynevelt M, Nguyen T, Cherninkova S, Bojinova V, et al. Autosomalrecessive congenital cerebellar ataxia is caused by mutations in metabotropic glutamate receptor 1. Am J Hum Genet. 2012;91:553-64.

67. Davarniya B, Hu H, Kahrizi K, Musante L, Fattahi Z, Hosseini M, Maqsoud F, Farajollahi R, Wienker TF, Ropers HH, Najmabadi $H$. The Role of a Novel TRMT1 Gene Mutation and Rare GRM1 Gene Defect in Intellectual Disability in Two Azeri Families. PLoS ONE. 2015;10, e0129631.

68. Onat OE, Gulsuner S, Bilguvar K, Nazli Basak A, Topaloglu H, Tan M, Tan U, Gunel M, Ozcelik T. Missense mutation in the ATPase, aminophospholipid transporter protein ATP8A2 is associated with cerebellar atrophy and quadrupedal locomotion. Eur J Hum Genet. 2013;21:281-5.

69. Sun Y, Almomani R, Breedveld GJ, Santen GW, Aten E, Lefeber DJ, Hoff Il, Brusse E, Verheijen FW, Verdijk RM, et al. Autosomal recessive spinocerebellar ataxia 7 (SCAR7) is caused by variants in TPP1, the gene involved in classic late-infantile neuronal ceroid lipofuscinosis 2 disease (CLN2 disease). Hum Mutat. 2013;34:706-13.

70. Dy ME, Sims KB, Friedman J. TPP1 deficiency: Rare cause of isolated childhood-onset progressive ataxia. Neurology. 2015;85:1259-61.

71. Margolin DH, Kousi M, Chan YM, Lim ET, Schmahmann JD, Hadjivassiliou M, Hall JE, Adam I, Dwyer A, Plummer L, et al. Ataxia, dementia, and hypogonadotropism caused by disordered ubiquitination. N Engl J Med 2013;368:1992-2003.

72. Santens P, Van Damme T, Steyaert W, Willaert A, Sablonniere B, De Paepe A, Coucke PJ, Dermaut B. RNF216 mutations as a novel cause of autosomal recessive Huntington-like disorder. Neurology. 2015;84:1760-6.

73. Hills LB, Masri A, Konno K, Kakegawa W, Lam AT, Lim-Melia E, Chandy N, Hill RS, Partlow JN, Al-Saffar M, et al. Deletions in GRID2 lead to a recessive syndrome of cerebellar ataxia and tonic upgaze in humans. Neurology. 2013;81:1378-86.

74. Van Schil K, Meire F, Karlstetter M, Bauwens M, Verdin H, Coppieters F, Scheiffert E, Van Nechel C, Langmann T, Deconinck N, De Baere E. Earlyonset autosomal recessive cerebellar ataxia associated with retinal dystrophy: new human hotfoot phenotype caused by homozygous GRID2 deletion. Genet Med. 2015;17:291-9.

75. Shi Y, Wang J, Li JD, Ren H, Guan W, He M, Yan W, Zhou Y, Hu Z, Zhang J, et al. Identification of CHIP as a novel causative gene for autosomal recessive cerebellar ataxia. PLoS ONE. 2013:8, e81884.

76. Synofzik M, Schule R, Schulze M, Gburek-Augustat J, Schweizer R, Schirmacher A, Krageloh-Mann I, Gonzalez M, Young P, Zuchner S, et al. Phenotype and frequency of STUB1 mutations: next-generation screenings in Caucasian ataxia and spastic paraplegia cohorts. Orphanet J Rare Dis. 2014;9:57.

77. Mallaret M, Synofzik M, Lee J, Sagum CA, Mahajnah M, Sharkia R, Drouot N, Renaud M, Klein FA, Anheim M, et al. The tumour suppressor gene WWOX is mutated in autosomal recessive cerebellar ataxia with epilepsy and mental retardation. Brain. 2014;137:411-9.

78. Ben-Salem S, Al-Shamsi AM, John A, Ali BR, Al-Gazali L. A novel whole exon deletion in WWOX gene causes early epilepsy, intellectual disability and optic atrophy. J Mol Neurosci. 2015:56:17-23.

79. Baple EL, Chambers H, Cross HE, Fawcett H, Nakazawa Y, Chioza BA, Harlalka GV, Mansour S, Sreekantan-Nair A, Patton MA, et al. Hypomorphic PCNA mutation underlies a human DNA repair disorder. J Clin Invest. 2014;124:3137-46.

80. Thomas AC, Williams H, Seto-Salvia N, Bacchelli C, Jenkins D, O'Sullivan M, Mengrelis K, Ishida M, Ocaka L, Chanudet E, et al. Mutations in SNX14 cause a distinctive autosomal-recessive cerebellar ataxia and intellectual disability syndrome. Am J Hum Genet. 2014;95:611-21.

81. Akizu N, Cantagrel V, Zaki MS, Al-Gazali L, Wang X, Rosti RO, Dikoglu E, Gelot AB, Rosti B, Vaux KK, et al. Biallelic mutations in SNX14 cause a syndromic form of cerebellar atrophy and lysosome-autophagosome dysfunction. Nat Genet. 2015;47:528-34.

82. Burns R, Majczenko K, Xu J, Peng W, Yapici Z, Dowling JJ, Li JZ, Burmeister M. Homozygous splice mutation in CWF19L1 in a Turkish family with recessive ataxia syndrome. Neurology. 2014;83:2175-82.

83. Nguyen M, Boesten I, Hellebrekers DM, Vanoevelen J, Kamps R, De Koning B, De Coo IF, Gerards M, Smeets HJ. Pathogenic CWF19L1 variants as a novel cause of autosomal recessive cerebellar ataxia and atrophy. Eur J Hum Genet. 2016;24:619-22.

84. Synofzik M, Haack TB, Kopajtich R, Gorza M, Rapaport D, Greiner M, Schonfeld C, Freiberg C, Schorr S, Holl RW, et al. Absence of BiP cochaperone DNAJC3 causes diabetes mellitus and multisystemic neurodegeneration. Am J Hum Genet. 2014;95:689-97. 
85. Guissart C, Li X, Leheup B, Drouot N, Montaut-Verient B, Raffo E, Jonveaux P, Roux AF, Claustres M, Fliegel L, Koenig M. Mutation of SLC9A1, encoding the major $\mathrm{Na}(+) / \mathrm{H}(+)$ exchanger, causes ataxia-deafness Lichtenstein-Knorr syndrome. Hum Mol Genet. 2015;24:463-70.

86. Bras J, Alonso I, Barbot C, Costa MM, Darwent L, Orme T, Sequeiros J, Hardy J, Coutinho P, Guerreiro R. Mutations in PNKP cause recessive ataxia with oculomotor apraxia type 4. Am J Hum Genet. 2015;96:474-9.

87. Paucar M, Malmgren H, Taylor M, Reynolds JJ, Svenningsson P, Press R, Nordgren A. Expanding the ataxia with oculomotor apraxia type 4 phenotype. Neurol Genet. 2016;2, e49.

88. Jobling RK, Assoum M, Gakh O, Blaser S, Raiman JA, Mignot C, Roze E, Durr A, Brice A, Levy N, et al. PMPCA mutations cause abnormal mitochondrial protein processing in patients with non-progressive cerebellar ataxia. Brain. 2015;138:1505-17.

89. Choquet K, Zurita-Rendon O, La Piana R, Yang S, Dicaire MJ, Boycott KM, Majewski J, Shoubridge EA, Brais B, Tetreault M. Autosomal recessive cerebellar ataxia caused by a homozygous mutation in PMPCA. Brain. 2016;139, e19.

90. Schmidt WM, Rutledge SL, Schule R, Mayerhofer B, Zuchner S, Boltshauser E, Bittner RE. Disruptive SCYL1 Mutations Underlie a Syndrome Characterized by Recurrent Episodes of Liver Failure, Peripheral Neuropathy, Cerebellar Atrophy, and Ataxia. Am J Hum Genet. 2015;97:855-61.

91. Kawarai T, Tajima A, Kuroda Y, Saji N, Orlacchio A, Terasawa H, Shimizu H, Kita Y, Izumi Y, Mitsui T, et al. A homozygous mutation of WA3B causes cerebellar ataxia with intellectual disability. J Neurol Neurosurg Psychiatry. 2016;87:656-62.

92. Gomez-Herreros F, Schuurs-Hoeijmakers JH, McCormack M, Greally MT, Rulten S, Romero-Granados R, Counihan TJ, Chaila E, Conroy J, Ennis S, et al. TDP2 protects transcription from abortive topoisomerase activity and is required for normal neural function. Nat Genet. 2014;46:516-21.

93. Duan R, Shi Y, Yu L, Zhang G, Li J, Lin Y, Guo J, Wang J, Shen L, Jiang H, et al. UBA5 Mutations Cause a New Form of Autosomal Recessive Cerebellar Ataxia. PLoS ONE. 2016;11, e0149039.

94. Edvardson S, Elbaz-Alon Y, Jalas C, Matlock A, Patel K, Labbe K, Shaag A, Jackman JE, Elpeleg O. A mutation in the THG1L gene in a family with cerebellar ataxia and developmental delay. Neurogenetics. 2016.

95. Sharp D, Blinderman L, Combs KA, Kienzle B, Ricci B, Wager-Smith K, Gil CM, Turck CW, Bouma ME, Rader DJ, et al. Cloning and gene defects in microsomal triglyceride transfer protein associated with abetalipoproteinaemia. Nature. 1993;365:65-9.

96. Carstea ED, Morris JA, Coleman KG, Loftus SK, Zhang D, Cummings C, Gu J, Rosenfeld MA, Pavan WJ, Krizman DB, et al. Niemann-Pick C1 disease gene: homology to mediators of cholesterol homeostasis. Science. 1997;277:228-31.

97. Naureckiene S, Sleat DE, Lackland H, Fensom A, Vanier MT, Wattiaux R, Jadot M, Lobel P. Identification of HE1 as the second gene of Niemann-Pick C disease. Science. 2000;290:2298-301.

98. Mihalik SJ, Morrell JC, Kim D, Sacksteder KA, Watkins PA, Gould SJ. Identification of PAHX, a Refsum disease gene. Nat Genet. 1997;17:185-9.

99. Jansen GA, Ofman R, Ferdinandusse S, ljlst L, Muijsers AO, Skjeldal OH, Stokke O, Jakobs C, Besley GT, Wraith JE, Wanders RJ. Refsum disease is caused by mutations in the phytanoyl-CoA hydroxylase gene. Nat Genet. 1997;17:190-3.

100. O'Dowd BF, Klavins MH, Willard HF, Gravel R, Lowden JA, Mahuran DJ. Molecular heterogeneity in the infantile and juvenile forms of Sandhoff disease (O-variant GM2 gangliosidosis). J Biol Chem. 1986;261:12680-5.

101. Myerowitz R, Costigan FC. The major defect in Ashkenazi Jews with TaySachs disease is an insertion in the gene for the alpha-chain of betahexosaminidase. J Biol Chem. 1988;263:18587-9.

102. Mahuran DJ. The biochemistry of HEXA and HEXB gene mutations causing GM2 gangliosidosis. Biochim Biophys Acta. 1991;1096:87-94.

103. Lise S, Clarkson Y, Perkins E, Kwasniewska A, Sadighi Akha E, Schnekenberg RP, Suminaite D, Hope J, Baker I, Gregory L, et al. Recessive mutations in SPTBN2 implicate beta-III spectrin in both cognitive and motor development. PLoS Genet. 2012;8, e1003074

104. Pierson TM, Adams D, Bonn F, Cherikuri PF, Teer JK, Hanson NF, Cruse P, Mullikin JC, Blakesley RW, Golas G, et al. Whole exome sequencing identifies AFG3L2 mutation in a novel recessive progressive myoclonic epilepsyataxia-neuropathy syndrome. Ann Neurol. 2010;68:S68-9.

105. Toro C, Landis D, DiBella D, Magri S, Lee P, Adams D, Jayadev S, Suwannarat $P$, Gahl W, Taroni F, Pierson TM. Phenotypic variation in AFG3L2-associated disorders. Ann Neurol. 2015;78:S110.

106. Synofzik M, Gonzalez MA, Lourenco CM, Coutelier M, Haack TB, Rebelo A, Hannequin D, Strom TM, Prokisch H, Kernstock C, et al. PNPLA6 mutations cause Boucher-Neuhauser and Gordon Holmes syndromes as part of a broad neurodegenerative spectrum. Brain. 2014;137:69-77.

107. Koh K, Kobayashi F, Miwa M, Shindo K, Isozaki E, Ishiura H, Tsuji S, Takiyama Y. Novel mutations in the PNPLA6 gene in Boucher-Neuhauser syndrome. J Hum Genet. 2015;60:217-20.

108. Gerber S, Alzayady KJ, Burglen L, Bremond-Gignac D, Marchesin V, Roche O, Rio M, Funalot B, Calmon R, Durr A, et al. Recessive and Dominant De Novo ITPR1 Mutations Cause Gillespie Syndrome. Am J Hum Genet. 2016;98:971-80.

109. Dor T, Cinnamon Y, Raymond L, Shaag A, Bouslam N, Bouhouche A, Gaussen M, Meyer V, Durr A, Brice A, et al. KIF1C mutations in two families with hereditary spastic paraparesis and cerebellar dysfunction. J Med Genet. 2014;51:137-42.

110. Caballero Oteyza A, Battaloglu E, Ocek L, Lindig T, Reichbauer J, Rebelo AP, Gonzalez MA, Zorlu Y, Ozes B, Timmann D, et al. Motor protein mutations cause a new form of hereditary spastic paraplegia. Neurology. 2014;82:2007-16.

111. Casari G, De Fusco M, Ciarmatori S, Zeviani M, Mora M, Fernandez P, De Michele G, Filla A, Cocozza S, Marconi R, et al. Spastic paraplegia and OXPHOS impairment caused by mutations in paraplegin, a nuclear-encoded mitochondrial metalloprotease. Cell. 1998;93:973-83.

112. Van Gassen KL, van der Heijden CD, De Bot ST, Den Dunnen WF, van den Berg $\mathrm{LH}$, Verschuuren-Bemelmans CC, Kremer HP, Veldink JH, Kamsteeg EJ, Scheffer $\mathrm{H}$, van de Warrenburg BP. Genotype-phenotype correlations in spastic paraplegia type 7: a study in a large Dutch cohort. Brain. 2012;135:2994-3004.

113. Tsaousidou MK, Ouahchi K, Warner TT, Yang Y, Simpson MA, Laing NG, Wilkinson PA, Madrid RE, Patel H, Hentati $F$, et al. Sequence alterations within CYP7B1 implicate defective cholesterol homeostasis in motor-neuron degeneration. Am J Hum Genet. 2008;82:510-5.

114. Lan MY, Yeh TH, Chang YY, Kuo HC, Sun HS, Lai SC, Lu CS. Clinical and genetic analysis of Taiwanese patients with hereditary spastic paraplegia type 5. Eur J Neurol. 2015;22:211-4

115. Stevanin G, Santorelli FM, Azzedine H, Coutinho P, Chomilier J, Denora PS, Martin E, Ouvrard-Hernandez AM, Tessa A, Bouslam N, et al. Mutations in SPG11, encoding spatacsin, are a major cause of spastic paraplegia with thin corpus callosum. Nat Genet. 2007;39:366-72.

116. Schule R, Schlipf N, Synofzik M, Klebe S, Klimpe S, Hehr U, Winner B, Lindig T, Dotzer A, Riess O, et al. Frequency and phenotype of SPG11 and SPG15 in complicated hereditary spastic paraplegia. J Neurol Neurosurg Psychiatry. 2009;80:1402-4

117. Hammer MB, Eleuch-Fayache G, Schottlaender LV, Nehdi H, Gibbs JR, Arepalli SK, Chong SB, Hernandez DG, Sailer A, Liu G, et al. Mutations in GBA2 cause autosomal-recessive cerebellar ataxia with spasticity. Am J Hum Genet. 2013;92:245-51.

118. Votsi C, Zamba-Papanicolaou E, Middleton LT, Pantzaris M, Christodoulou K. A novel GBA2 gene missense mutation in spastic ataxia. Ann Hum Genet. 2014;78:13-22.

119. Matthijs G, Schollen E, Pardon E, Veiga-Da-Cunha M, Jaeken J, Cassiman JJ, Van Schaftingen E. Mutations in PMM2, a phosphomannomutase gene on chromosome 16p13, in carbohydrate-deficient glycoprotein type I syndrome (Jaeken syndrome). Nat Genet. 1997;16:88-92.

120. Kjaergaard S, Skovby F, Schwartz M. Absence of homozygosity for predominant mutations in PMM2 in Danish patients with carbohydratedeficient glycoprotein syndrome type 1. Eur J Hum Genet. 1998;6:331-6.

121. Scheper GC, van der Klok T, Van Andel RJ, Van Berkel CG, Sissler M, Smet J, Muravina TI, Serkov SV, Uziel G, Bugiani M, et al. Mitochondrial aspartyl-tRNA synthetase deficiency causes leukoencephalopathy with brain stem and spinal cord involvement and lactate elevation. Nat Genet. 2007;39:534-9.

122. Tzoulis C, Tran GT, Gjerde IO, Aasly J, Neckelmann G, Rydland J, Varga V, Wadel-Andersen P, Bindoff LA. Leukoencephalopathy with brainstem and spinal cord involvement caused by a novel mutation in the DARS2 gene. J Neurol. 2012;259:292-6.

123. Doss S, Lohmann K, Seibler P, Arns B, Klopstock T, Zuhlke C, Freimann K Winkler S, Lohnau T, Drungowski M, et al. Recessive dystonia-ataxia syndrome in a Turkish family caused by a COX20 (FAM36A) mutation. J Neurol. 2014:261:207-12.

124. Yoshida K, Furihata K, Takeda S, Nakamura A, Yamamoto K, Morita H, Hiyamuta S, Ikeda S, Shimizu N, Yanagisawa N. A mutation in the ceruloplasmin gene is associated with systemic hemosiderosis in humans. Nat Genet. 1995:9:267-72.

125. Gregory A, Westaway SK, Holm IE, Kotzbauer PT, Hogarth P, Sonek S, Coryell JC, Nguyen TM, Nardocci N, Zorzi G, et al. Neurodegeneration associated with genetic defects in phospholipase A (2). Neurology. 2008;71:1402-9. 
126. Salih MA, Mundwiller E, Khan AO, AIDrees A, Elmalik SA, Hassan HH, AlOwain M, Alkhalidi HM, Katona I, Kabiraj MM, et al. New findings in a global approach to dissect the whole phenotype of PLA2G6 gene mutations. PLoS ONE. 2013;8, e76831.

127. Aldinger KA, Mosca SJ, Tetreault M, Dempsey JC, Ishak GE, Hartley T, Phelps IG, Lamont RE, O'Day DR, Basel D, et al. Mutations in LAMA1 cause cerebellar dysplasia and cysts with and without retinal dystrophy. Am J Hum Genet. 2014;95:227-34.

128. Rajadhyaksha AM, Elemento O, Puffenberger EG, Schierberl KC, Xiang JZ, Putorti ML, Berciano J, Poulin C, Brais B, Michaelides M, et al. Mutations in FLVCR1 cause posterior column ataxia and retinitis pigmentosa. Am J Hum Genet. 2010;87:643-54.

129. Ishiura H, Fukuda Y, Mitsui J, Nakahara Y, Ahsan B, Takahashi Y, Ichikawa Y, Goto J, Sakai T, Tsuji S. Posterior column ataxia with retinitis pigmentosa in a Japanese family with a novel mutation in FLVCR1. Neurogenetics. 2011;12:117-21.

130. Klockars T, Savukoski M, Isosomppi J, Peltonen L. Positional cloning of the CLN5 gene defective in the Finnish variant of the LINCL. Mol Genet Metab. 1999;66:324-8

131. Faruq M, Narang A, Kumari $R$, Pandey $R$, Garg A, Behari M, Dash D, Srivastava AK, Mukerji M. Novel mutations in typical and atypical genetic loci through exome sequencing in autosomal recessive cerebellar ataxia families. Clin Genet. 2014;86:335-41.

132. Verheijen FW, Verbeek E, Aula N, Beerens CE, Havelaar AC, Joosse M, Peltonen L, Aula P, Galjaard H, van der Spek PJ, Mancini GM. A new gene, encoding an anion transporter, is mutated in sialic acid storage diseases. Nat Genet. 1999;23:462-5.

133. Aula N, Salomaki P, Timonen R, Verheijen F, Mancini G, Mansson JE, Aula P, Peltonen L. The spectrum of SLC17A5-gene mutations resulting in free sialic acid-storage diseases indicates some genotype-phenotype correlation. Am J Hum Genet. 2000;67:832-40.

134. Ferland RJ, Eyaid W, Collura RV, Tully LD, Hill RS, Al-Nouri D, Al-Rumayyan A, Topcu M, Gascon G, Bodell A, et al. Abnormal cerebellar development and axonal decussation due to mutations in AHI1 in Joubert syndrome. Nat Genet. 2004:36:1008-13.

135. Cantagrel V, Silhavy JL, Bielas SL, Swistun D, Marsh SE, Bertrand JY, Audollent S, Attie-Bitach T, Holden KR, Dobyns WB, et al. Mutations in the cilia gene ARL13B lead to the classical form of Joubert syndrome. Am J Hum Genet. 2008;83:170-9.

136. Kleta R, Romeo E, Ristic Z, Ohura T, Stuart C, Arcos-Burgos M, Dave MH, Wagner CA, Camargo SR, Inoue S, et al. Mutations in SLC6A19, encoding B0AT1, cause Hartnup disorder. Nat Genet. 2004;36:999-1002.

137. Leegwater PA, Vermeulen G, Konst AA, Naidu S, Mulders J, Visser A, Kersbergen P, Mobach D, Fonds D, Van Berkel CG, et al. Subunits of the translation initiation factor elF2B are mutant in leukoencephalopathy with vanishing white matter. Nat Genet. 2001;29:383-8.

138. Fogli A, Schiffmann R, Bertini E, Ughetto S, Combes P, Eymard-Pierre E, Kaneski $C R$, Pineda M, Troncoso M, Uziel G, et al. The effect of genotype on the natural history of elF2B-related leukodystrophies. Neurology. 2004;62:1509-17.

139. Topcu M, Jobard F, Halliez S, Coskun T, Yalcinkayal C, Gerceker FO, Wanders RJ, Prud'homme JF, Lathrop M, Ozguc M, Fischer J. L-2-Hydroxyglutaric aciduria: identification of a mutant gene C14orf160, localized on chromosome 14q22.1. Hum Mol Genet. 2004;13:2803-11.

140. Steenweg ME, Jakobs C, Errami A, Van Dooren SJ, Adeva Bartolome MT, Aerssens P, Augoustides-Savvapoulou P, Baric I, Baumann M, Bonafe L, et al. An overview of L-2-hydroxyglutarate dehydrogenase gene ( $\mathrm{L} 2 \mathrm{HGDH})$ variants: a genotype-phenotype study. Hum Mutat. 2010;31:380-90.

141. Corbett MA, Schwake M, Bahlo M, Dibbens LM, Lin M, Gandolfo LC, Vears DF, O'Sullivan JD, Robertson T, Bayly MA, et al. A mutation in the Golgi QbSNARE gene GOSR2 causes progressive myoclonus epilepsy with early ataxia. Am J Hum Genet. 2011;88:657-63.

142. Bernard G, Chouery E, Putorti ML, Tetreault M, Takanohashi A, Carosso G, Clement I, Boespflug-Tanguy O, Rodriguez D, Delague V, et al. Mutations of POLR3A encoding a catalytic subunit of RNA polymerase Pol III cause a recessive hypomyelinating leukodystrophy. Am J Hum Genet. 2011;89:415-23.

143. Bonneau D, Colin E, Oca F, Ferre M, Chevrollier A, Gueguen N, DesquiretDumas V, N'Guyen S, Barth M, Zanlonghi X, et al. Early-onset Behr syndrome due to compound heterozygous mutations in OPA1. Brain. 2014;137, e301.

144. Lee J, Jung SC, Hong YB, Yoo JH, Koo H, Lee JH, Hong HD, Kim SB, Chung KW, Choi BO. Recessive optic atrophy, sensorimotor neuropathy and cataract associated with novel compound heterozygous mutations in OPA1. Mol Med Rep. 2016;14:33-40.

\section{Submit your next manuscript to BioMed Central and we will help you at every step:}

- We accept pre-submission inquiries

- Our selector tool helps you to find the most relevant journal

- We provide round the clock customer support

- Convenient online submission

- Thorough peer review

- Inclusion in PubMed and all major indexing services

- Maximum visibility for your research

Submit your manuscript at www.biomedcentral.com/submit 